\title{
Method for Equalizing Switching Loss of MOSFETs Caused by the Wiring Structure Connected in Parallel
}

\author{
Tatsuya Okuda Member (Mitsubishi Electric Corporation, Okuda.Tatsuya@cb.MitsubishiElectric.co.jp) \\ Takahiro Urakabe Member (Mitsubishi Electric Corporation) \\ Takeshi Ohi Member (Mitsubishi Electric Corporation)
}

Keywords: MOSFET, wiring structure, gate wiring, electromagnetic induction, switching characteristics, parallel connection

The electromagnetic field environment around a power semiconductor device is extremely important. This is because it can potentially affect the switching speed and thereby the switching loss of the device. Electromagnetic induction due to switching of devices causes a change in the gate voltage of the devices. This change in the gate voltage during the switching period causes drastic increase in current at short circuit and concentration of switching loss when many devices are connected in parallel.

In this paper, we describe the influence of the wiring structure of power semiconductor devices on their switching characteristics using three-dimensional electromagnetic field analysis and circuit simulation. We also describe methods to improve the switching problems caused by the wiring structure of the main circuit and control circuit.

Fig. 1 shows an analysis model of sample 1 . Sample 1 composes a half bridge circuit with four MOSFETs connected in parallel. These MOSFETs (FET1, 2 and FET3, 4) are symmetric with respect to the $\mathrm{X}$-axis and gate wiring are closed to control source wiring.

Fig. 2 shows the simulation results for gate voltage and drain current waveforms at that instance when all four MOSFETs are turned off. It can be clearly seen that the drain current is concentrated on FET1 and FET2 because the gate voltages of FET1 and FET2 are

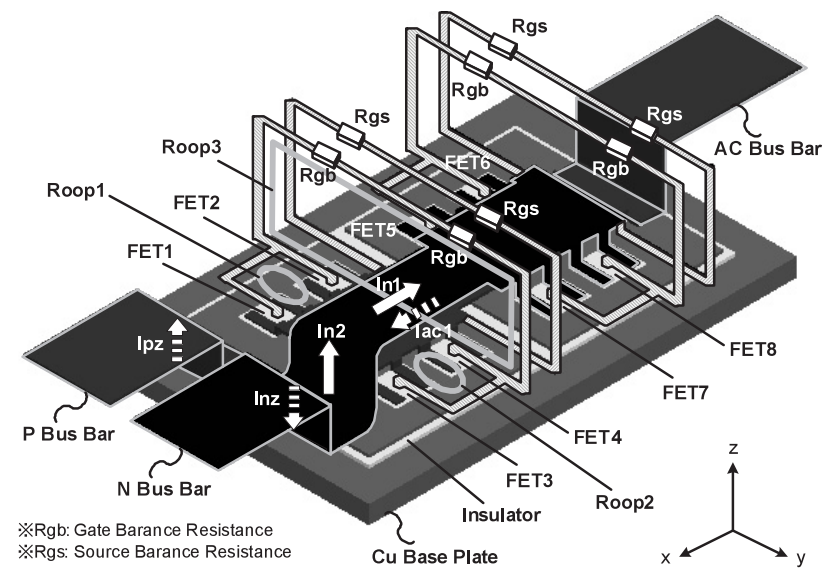

Fig. 1. Analysis model of sample 1 much higher than the gate voltages of FET3 and FET4. This concentration of drain current on FET1 and FET2 is due to the electromagnetic induction from the main wiring structure.

Fig. 3 shows the turn off loss ratio of there analysis models. Sample 2 is an analysis model with on optimized main wiring structure and sample 3 is an analysis model with on optimized gate wiring structure. The switching loss of the most affected MOSFET could be reduced from $160 \%$ to $110 \%$, if the optimized wiring structure is used.

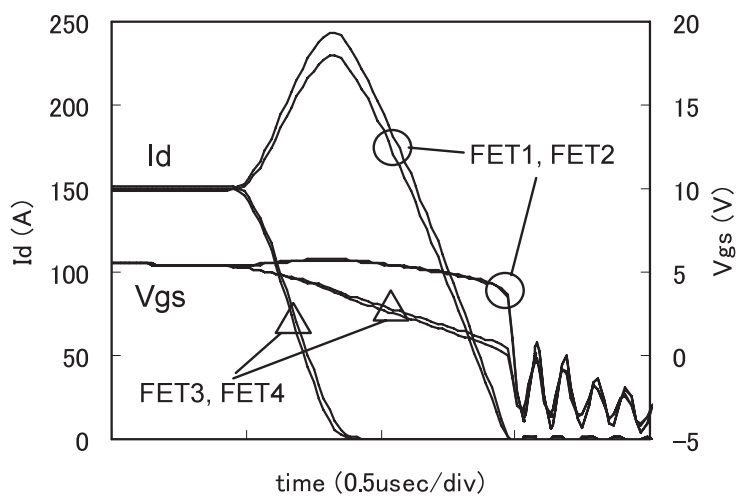

Fig. 2. Turn off waveforms of High side MOSFETs of sample 1

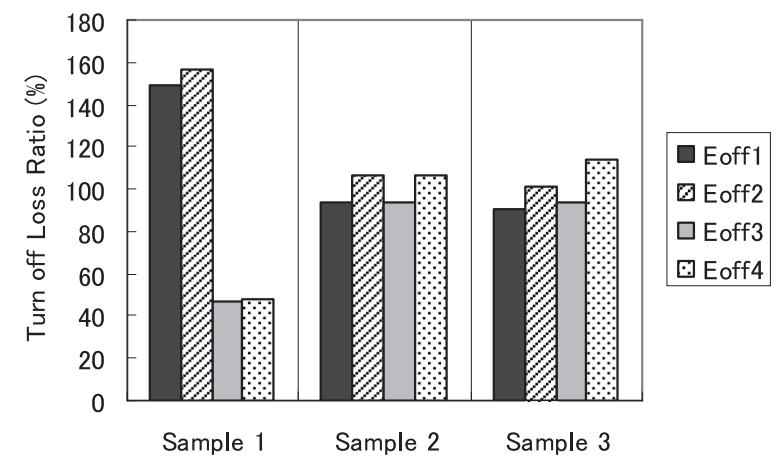

Fig. 3. Turn off loss ratio of analysis models 


\title{
配線構造に起因する多並列 MOSFET の スイッチング損失均等化
}

\author{
正 員 奥田 達也* 正 員 浦壁 隆浩* \\ 正 員 大井 健史*
}

\section{Method for Equalizing Switching Loss of MOSFETs Caused by the Wiring Structure Connected in Parallel}

Tatsuya Okuda*, Member, Takahiro Urakabe*, Member, Takeshi Ohi*, Member

\begin{abstract}
The electromagnetic field environment around a power semiconductor device is extremely important. This is because it can potentially affect the switching speed and thereby the switching loss of the device. Electromagnetic induction due to switching of devices causes a change in the gate voltage of the devices. This change in the gate voltage during the switching period causes drastic increase in current at short circuit and concentration of switching loss when many devices are connected in parallel.

In this paper, we describe the influence of the wiring structure of power semiconductor devices on their switching characteristics using three-dimensional electromagnetic field analysis and circuit simulation. We also describe methods to improve the switching problems caused by the wiring structure of the main circuit and control circuit.
\end{abstract}

キーワード：MOSFET, 配線構造, ゲート配線, 電磁誘導, スイッチング特性, 並列接続

Keywords: MOSFET, wiring structure, gate wiring, electromagnetic induction, switching characteristics, parallel connection

\section{1. まえがき}

電圧駆動形素子である MOSFET や IGBT は高速スイッ チングが可能であり, パワエレ機器の小型化・低損失化に 大きく貢献している。しかし, MOSFET や IGBT の高速 化・高密度実装化に伴い, 配線間の電磁干渉が素子動作に 及ぼす影響が無視できなくなってきている。

配線間の電磁干渉で特に問題となる現象の一つに，ター ンオン時のコレクタ電流上昇時に，ゲート電圧に正の誘導 起電圧が重畳して印加され，スイッチング速度が早くなる 正帰還動作がある。文献(1)では，アーム短絡時における IGBT の正帰還動作に伴う，異常電流の解析に関する報告 がなされている。

大電流定格のパワー半導体モジュールでは, 多数の半導 体チップ並列接続されるため, 各チップの発生損失を均等化 する必要がある。文献(2)では, MOSFET のアバランシェ 電圧ばらつきによって発生するスイッチング損失ばらつき を均等化する手法として, サージエネルギーをMOSFET の チャネル抵抗で消費させる方式が報告されている。

\footnotetext{
三菱電機（株）先端技術総合研究所

于 661-8661 尼崎市塚口本町 8-1-1

Advanced Technology R\&D Center, Mitsubishi Electric Corp.

8-1-1, Tsukaguchi-Honmachi, Amagasaki 661-8661
}

一方, 多並列接続された半導体チップの損失ばらつき要 因として, 上記チップ特性ばらつき以外に, 配線構造に起 因するゲート電圧ばらつきが考えられる。文献 (3)では, 配 線構造に起因する並列チップ間の過渡電流アンバランスに ついて，電磁界解析を用いた報告がされている。

このように, 配線構造に起因するスイッチング特性への 影響に関する報告はあるものの, 並列チップ間の過渡電流 アンバランスについて，定量的に具体的な方策を示した報 告例はこれまでない。

本論文では, 配線構造に起因するスイッチング損失ばら つきに着目し, 三次元電磁界解析と回路解析を用いて, そ の発生要因を明らかにするとともに, 多並列接続された半 導体チップのスイッチング損失を均等化するための配線構 造について論じる。第 2 章では, スイッチング特性に影響 を及ぼす正帰還動作と負帰還動作の発生要因と, 並列チッ プ間のゲート電圧ばらつきが発生する要因について述べる。 第 3 章では, MOSFET を 4 並列接続したパワー半導体モ ジュールにおいて, 配線構造に起因する過渡電流ばらつきへ の影響と, バランス抵抗によるスイッチング損失ばらつきへ の影響の解析を行う。第 4 章では, 主回路配線構造やゲー 卜配線構造の最適化により, 配線構造に起因するスイッチ ング損失ばらつきを均等化するための手法について述べる。 


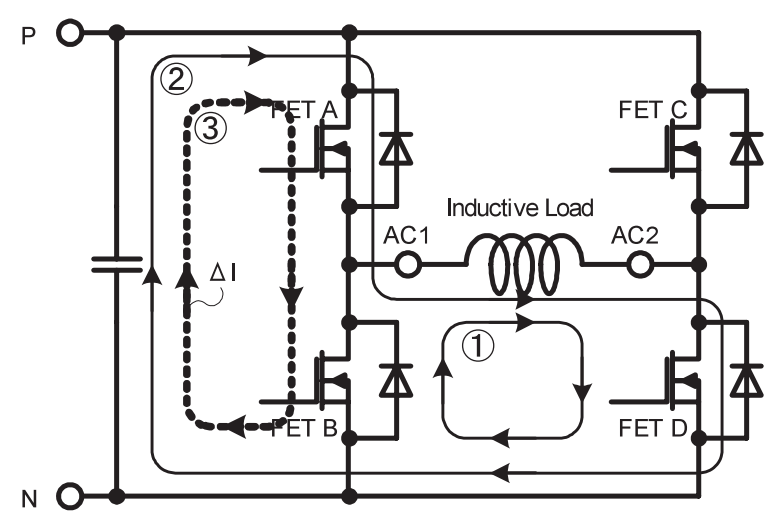

図 1 スイッチング前後の電流変化

Fig. 1. Change of current path at MOSFET switching.

\section{2. ゲート電圧変動の発生要因}

〈2・1 $\rangle$ スイッチングに発生する磁束変化 電磁誘導 による誘導起電圧 $\mathrm{V}$ は, $\mathrm{V}=-\mathrm{d} \phi / \mathrm{dt}$ で表され，ある回路 に鎖交する磁束量 $\phi$ の時間変化によって発生する。磁束密 度は電流值と電流経路によりほほ一意的に決まるため，ス イッチング時に発生する誘導起電圧を考えるには, スイッ チング前後の電流変化を把握しておく必要がある。

図 1 に，フルブリッジ回路の High 側 MOSFET (FET A) がターンオンする前後の電流経路を示す。(1) FET A の ターンオン直前の電流経路，(2はターンオン後の電流経路 を示している。これより, FET Aのターンオン時の電流変 化 $\Delta \mathrm{I}$ は，アーム短絡電流やダイオードの逆回復電流が流れ る時（電流経路(3)）の電流変化経路と同じとなる。ターン オフ時はターンオン時と逆の電流変化となるので, 電流経 路(3に矢印と反対方向の電流を流した時の電流変化 $(-\Delta \mathrm{I})$ と同じとなる。

〈2·2 $\rangle$ 正帰還動作と負帰還動作 図 2 に, ハーフブ リッジを構成する，一般的なパワー半導体モジュールの簡 易模式図を示す。MOSFET のドレイン電極は配線導体 $(\mathrm{Cu}$ Pattern）上に半田接続されており, ソース電極は $\mathrm{Al}$ ワイヤ により他の配線導体に接続される。MOSFET のゲート駆

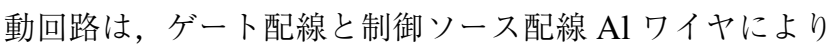
接続される。なお, High 側 MOSFET のゲート駆動回路と 配線は省略している。図 2 には, ターンオン時の電流変化 $\Delta \mathrm{I}$ と，それによって発生する磁束変化 $\Delta \mathrm{B}$ の方向も示して いる。

ターンオン時の電流変化 $\Delta \mathrm{I}$ によって, Low 側 MOSFET のゲート配線と制御用ソース配線には紙面に対して上向き の磁束変化 $\Delta \mathrm{B}$ が発生し, 磁束変化 $\Delta \mathrm{B}$ によって発生する 誘導起電圧 $-\mathrm{d} \Phi / \mathrm{dt}$ はゲートを充電する方向に誘導電流を 流す。このように，ターンオン時に，ゲート電圧に正の誘 導起電圧が等価的に印加されること正帰還動作という。正 帰還動作は，スイッチング時のゲート電荷の充放電を促進 するため, スイッチング速度が速くなり, 短絡時の異常な過 電流による SCSOA（Short Circuit Safety Operation Area）

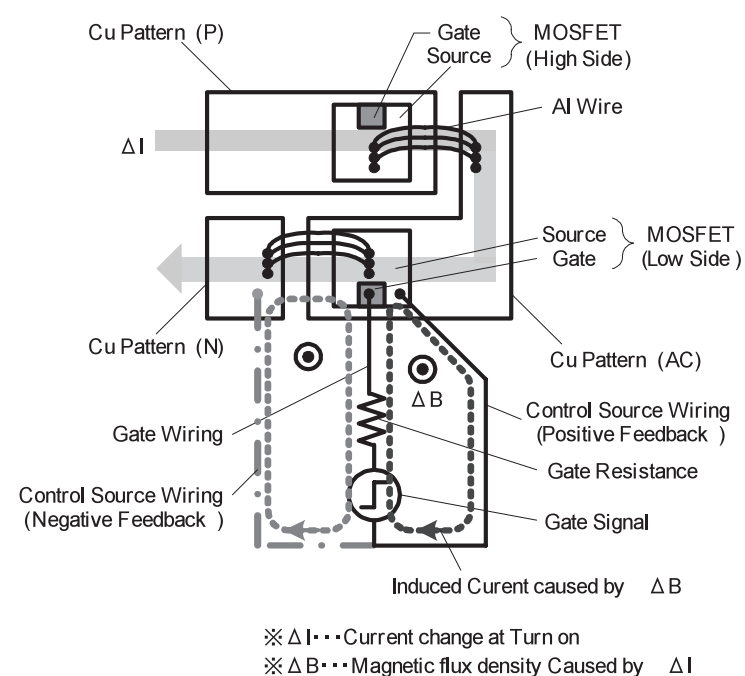

図 2 正帰還動作と負帰還動作

Fig. 2. Positive feedback and negative feedback of gate voltage.

の悪化, ターンオン時の $\mathrm{d} / / \mathrm{dt}$ 増加によるダイオードリカバ リー破壊耐量の低下，ターンオフ時の $\mathrm{d} \mathrm{I} / \mathrm{dt}$ 増加によるサー ジ電圧増加といった不具合要因となる。

逆に, ターンオン時に, ゲート電圧に負の誘導起電圧が 等価的に印加されること負帰還動作という。負帰還動作は, スイッチング時のゲート電荷の充放電を妨げる方向に作用 するため, スイッチング動作は安定する。例えば, 図 2 の点 線部で示した位置に制御用ソース配線を変更すると, ゲー 卜配線に流れる誘導電流が反転するため, 負帰還動作とな る。しかし, 過剩な負帰還動作はスイッチング損失の増大 を招くので，適切な配線設計が必要である。

$\langle\mathbf{2} \cdot \mathbf{3}\rangle$ 並列チップ間のゲート電圧変動ＭOSFET を 多並列接続する場合, 主に素子のオン抵抗, 素子温度, お よび主回路インピーダンスのアンバランスにより定常損失 ばらつきが発生する。また, MOSFET のしきい值電圧やア バランシェ電圧, 電磁誘導によるゲート電圧ばらつきによ りスイッチング損失ばらつきが発生する。スイッチング損 失ばらつきが発生すると, チップ温度にばらつきが発生す るため，高発熱チップの熱的破壊が懸念される。

パワー半導体モジュールに扔いては, ゲート配線と主回 路配線との電磁誘導をなくすことは不可能である。スイッ チング損失を均等化するためには，単に負帰還か正帰還か が問題ではなく, 電磁誘導の結果, 各チップに発生するゲー 卜電圧を均一化できる配線構造が必要である。

各 MOSFET のゲート電圧ばらつきが発生する要因につ いて説明する。図 3 に, High 側素子と Low 側素子の MOSFET 2 並列接続して構成した，一般的なパワー半導体モ ジュールの簡易模式図と, ターンオフ時の電流変化によっ て発生する磁束変化方向を示す。各 MOSFET の制御ゲー 卜配線にはゲートバランス抵抗 $(\mathrm{Rg} 1, \mathrm{Rg} 2)$ を, 制御用 ソース配線にはソースバランス抵抗（Rs1，Rs2）を接続し 


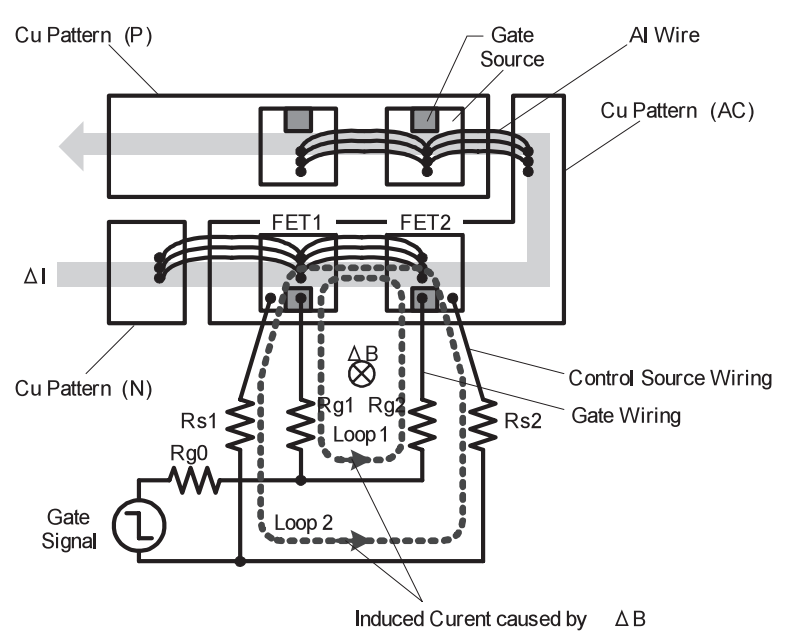

図 3 並列接続時のゲート電圧変動

Fig. 3. Gate voltage unbalance of parallel MOSFETs.

ている。

MOSFET を並列接続する場合, MOSFET のゲートーソー 又間容量 Cgs を介して，ゲート配線と主回路ソース配線で 構成されるゲート配線ループ（ループ 1) が必ず構成され る。ゲート配線ループ内の磁束変化 $\Delta \mathrm{B}$ が発生すると, そ の誘導起電圧一 $\mathrm{d} \Phi / \mathrm{dt}$ によって MOSFET 間のゲート電圧 ばらつきが発生し，スイッチング損失ばらつきが発生する。

図 3 の構成では, FET1 と FET2 のターンオフ時に, ゲー ト配線ループ（ループ1）に，紙面に対して下向きの磁束変 化が発生するため, MOSFET1 のゲート放電電流は増加さ せる方向に, MOSFET2 のゲート放電電流は減少させる方向 に誘導電流が流れる。その結果, MOSFET2 よりもMOSFET1 のスイッチング速度が速くなり，スイッチング損失 ばらつきが発生する。

\section{3. 配線構造によるスイッチング損失ばらつき}

具体的なパワー半導体モジュールの構造例を用いて, 配 線構造によるスイッチング損失ばらつきへの影響を, シミュ レーションにより評価する。シミュレーションでは，三次 元電磁界解析によりモジュール内部の配線間の電磁結合を 定量化した回路モデルを構築し, 回路解析べースで誘導負 荷をスイッチングした時の, ゲート電圧変動やスイッチン グ損失ばらつきの評価を行う。

〈3.1〉解析モデル 図 4 にハーフブリッジ構成のパ ワー半導体モジュールの 3D 解析モデル（解析サンプル 1) を，図 5 に解析サンプル 1 の上面図を，図 6 に解析サンプル 1 の等価回路図を示す。High 側 MOSFET としての FET1〜 FET4, Low 側 MOSFET としての FET5〜FET8 はそれぞ れ 4 並列接続している。各 MOSFET のドレイン電極は, $\mathrm{Cu}$ ベース板上に固定された DBC（Direct Bond Copper）基板 上の配線パターンに半田で接合され，FET1〜 FET4 のソー 久電極は ACバスバーに, FET5〜FET8 のソース電極は N バスバーに接続される。ゲート配線と制御用ソース配線は,

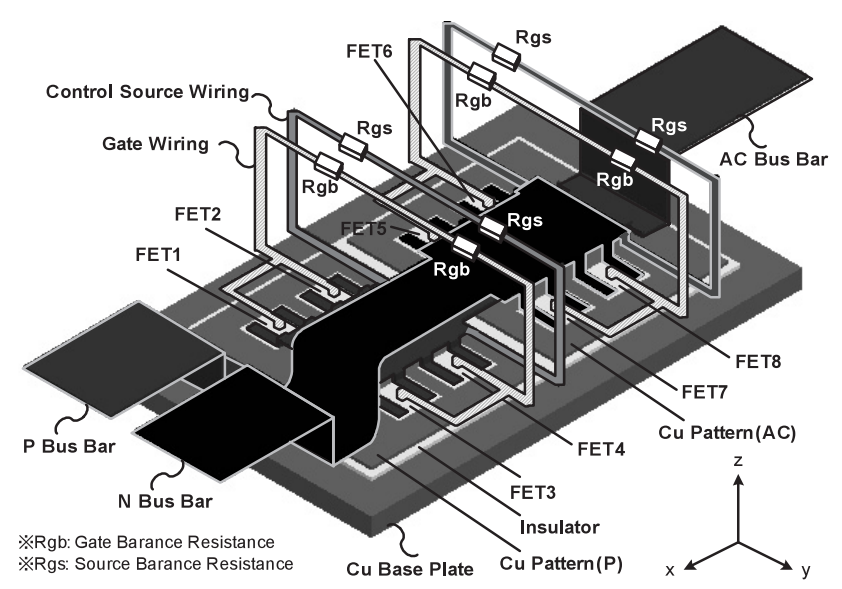

図 43 D 解析サンプル 1

Fig. 4. 3D-Analysis model of sample 1.

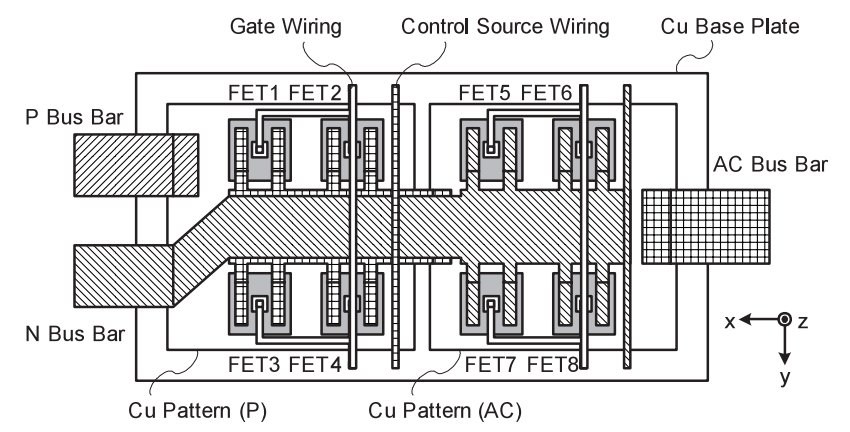

図 5 解析サンプル 1 の上面図

Fig. 5. Analysis model of sample 1.

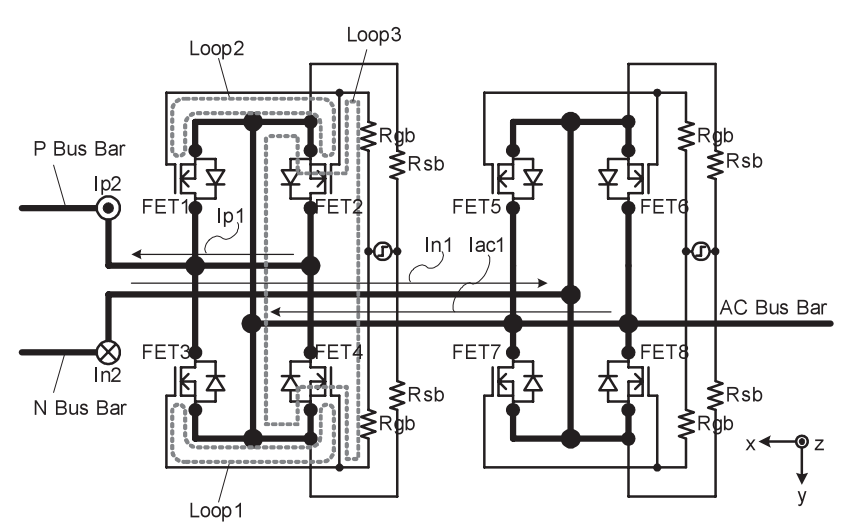

図 6 解析サンプル 1 の等価回路

Fig. 6. Circuit of of sample 1.

隣り合う 2 個の MOSFET を一対とし, AC バスバーと N バスバーに対して対称となるように上方に引き出し，ゲー トバランス抵抗 Rgb とソースバランス抵抗 Rgs を介して それぞれ接続される。

このように，解析サンプル 1 では並列接続された MOSFET 間の配線インピーダンスを均一にするため, 並列接続 される MOSFETを， ACバスバーと N バスバーに対して 対称となるように配置している。

$\langle\mathbf{3} \cdot \mathbf{2}\rangle$ ターンオフ波形 低電圧・大電流定格のパワー 


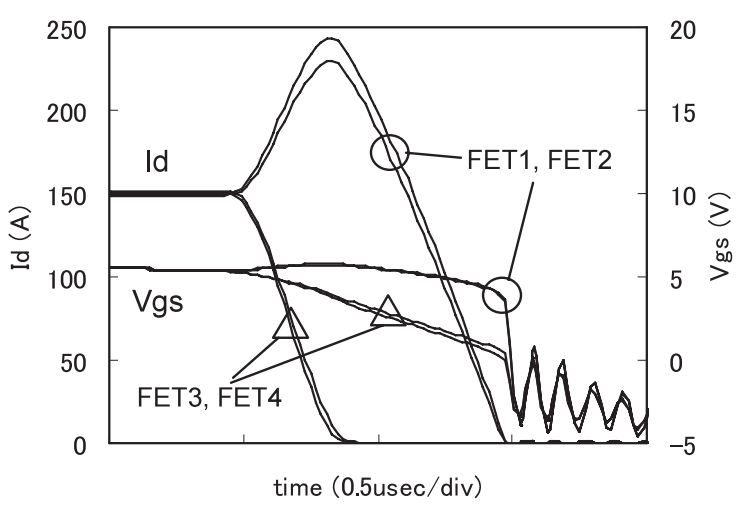

図 7 サンプル 1 の High 側 MOSFET の ターンオフ波形

Fig. 7. Turn off waveforms of High side MOSFETs of sample 1.

半導体モジュールでは, 電源電圧に対して, スイッチング 時に配線インダクタンスに印加される電圧比率が大きくな る。ターンオン時に MOSFET のドレインーソース間に印加 される電圧は非常に低く, ゼロ電圧スイッチングに近い波 形となるのに対し，ターンオフ時に印加されるサージ電圧 は大きくなる。その結果, 低電圧・大電流定格のパワー半 導体モジュールでは, ターンオフ損失に比べてターンオン 損失はほぼ無視できるため，本論文ではターンオフ波形に ついて評価する。

図 7 に, High 側 MOSFET のターンオフ波形を示す。図 中, ターンオフ時の各 MOSFET のドレイン電流波形とゲー 卜電圧波形を示している。シミュレーション条件は，電源

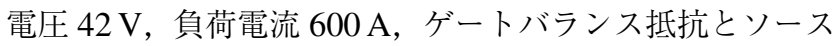
バランス抵抗は共に $1 \Omega$ とし，各 MOSFET の特性は全て 同じモデルを使用した。ターンオフ時のドレイン電流変化 が開始するとともにゲート電圧ばらつきが発生し, FET1 と FET2 に過渡的に電流が集中している。

解析モデル 1 のように, 並列接続された MOSFET を AC バスバーと $\mathrm{N}$ バスバーに対して対称となるように配置して も，過大な過渡電流ばらつきが発生する。

$\langle\mathbf{3} \cdot \mathbf{3}\rangle$ ゲート電圧ばらつきの発生要因 解析サンプ ル 1 では, FET1 と FET2 のゲート配線ループ (Loop1), FET3 と FET4 のゲート配線ループ (Loop2), FET1， 2 と FET3，4のゲート配線ループ (Loop3) が存在する。Loop1 への鎖交磁束は FET1 と FET2 の電流ばらつきを, Loop2 への鎖交磁束は FET3 と FET4 の電流ばらつきを，Loop3 への鎖交磁束は FET1，2 と FET3，4 の電流ばらつきを誘 発する要因となる。

High 側 MOSFET のターンオフ時, $\mathrm{N}$ バスバーを $-\mathrm{x}$ 軸 方向に流れる電流成分 $\mathrm{In} 1$ により発生する磁束と, $\mathrm{AC}$ バ スバーを $\mathrm{x}$ 軸方向に流れる電流成分 $\mathrm{Iac} 1$ と P 側配線を $\mathrm{x}$ 軸方向に流れる電流成分 Ip1 によって発生する磁束により, $\mathrm{z}$ 軸方向の磁束はほぼ打ち消されるため, $\mathrm{xy}$ 平面上に構成 されているLoop1 とLoop2への鎖交磁束はほとんどない。

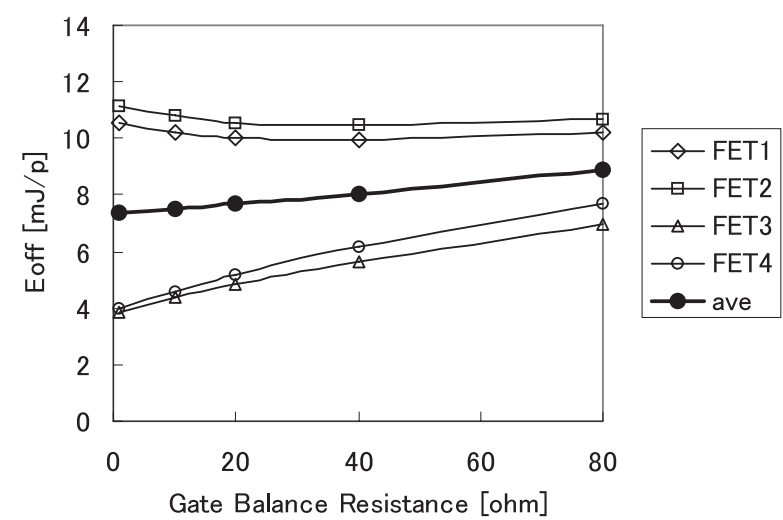

図 8 ゲートバランス抵抗とターンオフ損失の関係

Fig. 8. Relationship between Gate Balance Resistance and Eoff.

また, Loop3 は yz 平面上に構成されているため, $\mathrm{x}$ 軸方向 の電流成分 Iac1 と In1，Ip1 による磁束は鎖交しない。

次に, $\mathrm{N}$ バスバーを $-\mathrm{Z}$ 軸方向に流れる電流成分 In 2 と $\mathrm{P}$ バスバーを $\mathrm{z}$ 軸方向に流れる電流成分 Ip 2 によって発生す る磁束について検討する。In2 とIp2 は互いに逆向きの電 流成分だが，Loop3 が構成される場所はy 軸方向の鎖交磁 束はほぼ打ち消されるものの, $\mathrm{x}$ 軸方向の鎖交磁束は打ち 消されず, Loop3 には $-\mathrm{x}$ 軸方向の磁束が鎖交する。Loop3 への $-\mathrm{x}$ 軸方向の鎖交磁束は, FET1 と FET2 のゲート電荷 を充電し, FET3 と FET4 のゲート電荷を放電する方向に 誘導起電圧を発生させる。その結果, FET1 と FET2 の夕ー ンオフ速度は遅く, FET3 と FET4 のターンオフ速度は速 くなり, FET1 と FET2 に過渡的な電流集中が発生すると 考えられる。

〈3.4〉 バランス抵抗によるターンオフ損失ばらつき改 善効果＼cjkstart各 MOSFET のゲート間に接続しているゲート バランス抵抗によるターンオフ損失ばらつきの改善効果に ついて検証する。図 8 に, ゲートバランス抵抗とターンオ フ損失の関係を示す。ゲートバランス抵抗を大きくすると, ゲート配線を流れる誘導電流が減少するため, 各 MOSFET のターンオフ損失ばらつきを低減することができる。しか し，ゲートバランス抵抗を大きくするとスイッチング速度 が低下するため, 平均ターンオフ損失が増加し, 電流集中 する FET1 と FET2 のターンオフ損失はほとんど下がらな い。逆に, 平均損失が増加することで, 効率低下・冷却装 置の大型化等の問題が発生する。

次に，各 MOSFET の制御ソース間に接続するソースバ ランス抵抗による過渡電流ばらつき改善効果について検証 する。図 9 に, ソースバランス抵抗とターンオフ損失, 制 御用ソース配線を流れる誘導電流の関係を示す。ソースバ ランス抵抗を小さくすると, 制御用ソース配線を流れる誘 導電流が増加し，この電流がゲート配線に流れる誘導電流 を低減する方向に流れるため，ターンオフ損失ばらつきを 抑制する方向に作用するが，改善効果はほとんどなかった。 また，ソースバランス抵抗を小さくすると，制御用ソース 


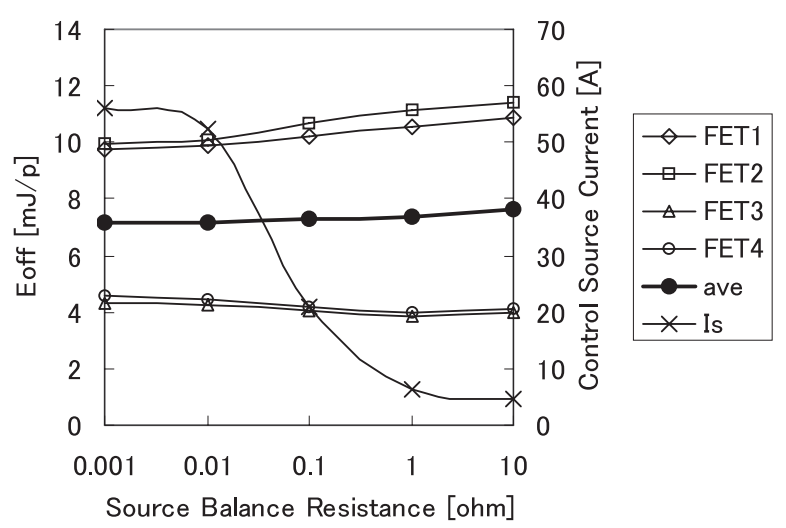

図 9 ソースバランス抵抗とターンオフ損失の関係

Fig. 9. Relationship between Source Balance Resistance and Control Source Current and Eoff.

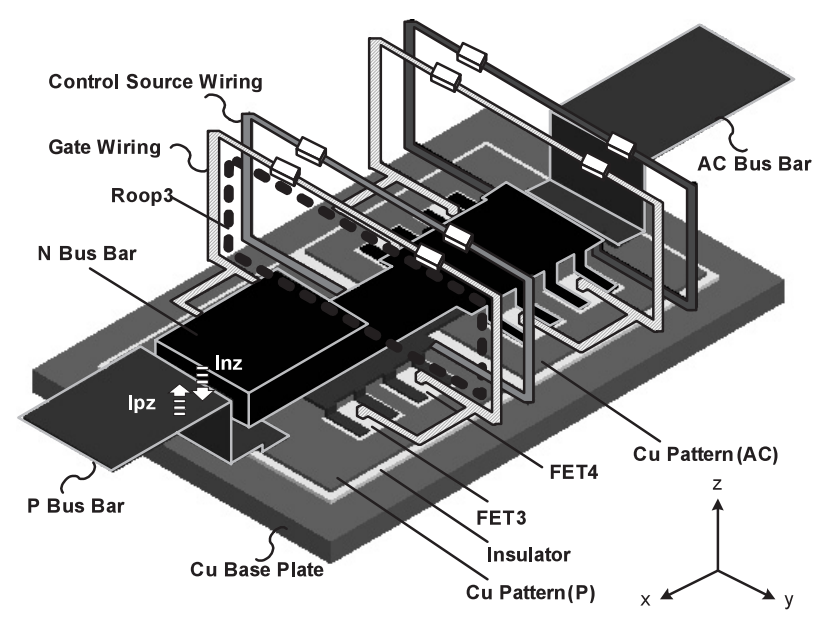

図 10 解析サンプル 2

Fig. 10. Analysis model of sample 2.

配線に $50 \mathrm{~A}$ 以上もの電流が流れてしまうため, 制御用ソー 又配線の過大温度上昇や断線といった問題が発生する。

以上より, バランス抵抗によるターンオフ損失ばらつき の改善効果は小さく, また, 新たな課題も発生するため, 配 線構造レベルでの最適化を行う必要がある。

\section{4. 配線構造の最適化によるスイッチング損失の 均等化}

ゲート配線ループ（Loop3）への磁束鎖交量を低減する ため, 主回路配線構造の最適化によるアプローチと, ゲー 卜配線構造の最適化によるアプローチについて述べる。

$\langle\mathbf{4} \cdot \mathbf{1}\rangle$ 主回路配線構造の最適化 図 10 に, 主回路配 線構造のみを変更した場合の解析モデル（解析サンプル 2) を示す。解析サンプル 2 では, $\mathrm{N}$ バスバーの $\mathrm{y}$ 軸方向への 曲げ部分をなくし， N バスバーと $\mathrm{P}$ バスバーが $\mathrm{x}$ 軸方向に 対向する構造とした。このような構造にすることで， $\mathrm{N}$ バ スバーの $-\mathrm{z}$ 軸方向の電流成分 $\mathrm{Inz}$ と, $\mathrm{P}$ バスバーの $\mathrm{z}$ 軸方 向の電流成分 Ipz によって発生する漏机磁束は, $-\mathrm{x}$ 軸方向 ではなく -y 軸となる。Loop3 はyz 平面で構成しているた

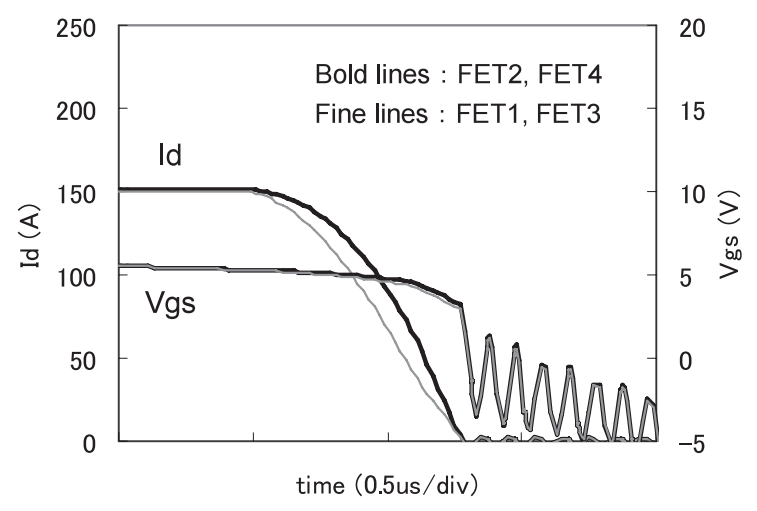

図 11 サンプル 2 のターンオフ波形

Fig. 11. Turn off waveforms of sample 2.

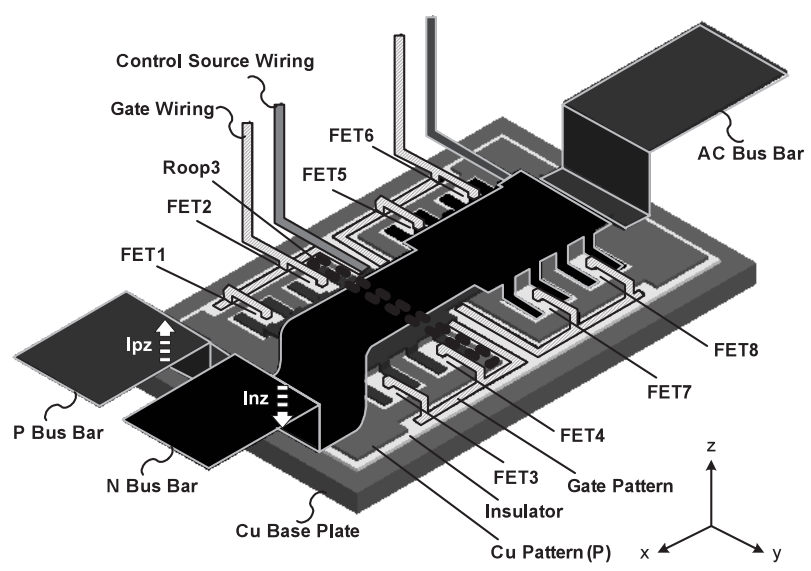

図 12 解析サンプル 3

Fig. 12. Analysis model of sample 3.

め, ターンオフ時に Loop3 に鎖交する $\mathrm{x}$ 軸方向の磁束をな くすことができる。

図 11 に, 解析サンプル 2 のシミュレーション結果を示 す。図中, ターンオフ時の各 MOSFET のドレイン電流波 形とゲート電圧波形を示している。FET1 と FET3 のドレ イン電流, 及び, FET2 と FET4 のドレイン電流は一致し ており, Loop3への鎖交磁束削減による電流均等化効果を 確認できた。

このように，並列接続された MOSFET 間のゲート配線 ループと, P バスバーと $\mathrm{N}$ バスバーの外部接続端子配列方 向を垂直にし，ゲート配線ループと主回路配線間の磁気結 合を低減することで，スイッチング時の過渡電流ばらつき を抑制することができる。

$\langle\mathbf{4} \cdot \mathbf{2}\rangle$ ゲート配線構造の最適化 パワー半導体モジ ユールでは機器搭載の関係上, 外部接続端子の位置を変更 することができない場合がある。そこで，主回路配線を変 更せずに，ゲート配線構造の最適化によるスイッチング損 失の均等化を検討する。

図 12 に, ゲート配線構造のみを変更した場合の解析モ デル（解析サンプル 3）を示す。解析サンプル 3 では, 各 MOSFET のゲート配線を DBC 基板上の配線パターンで一 


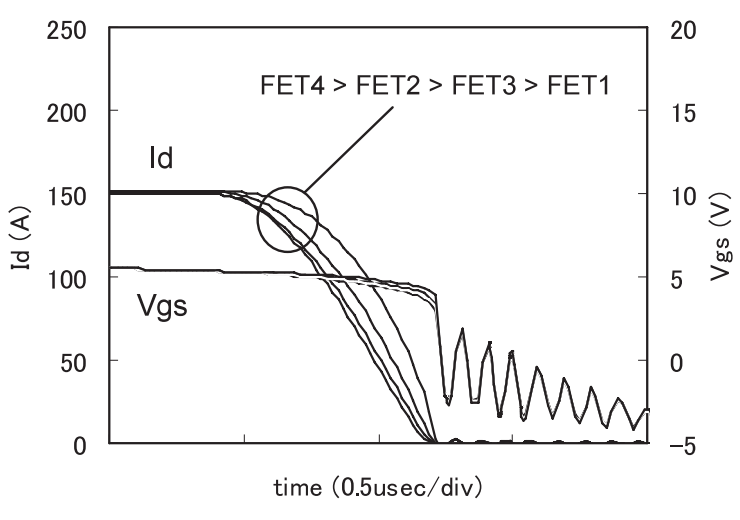

図 13 サンプル 3 のターンオフ波形

Fig. 13. Turn off waveforms of sample 3.

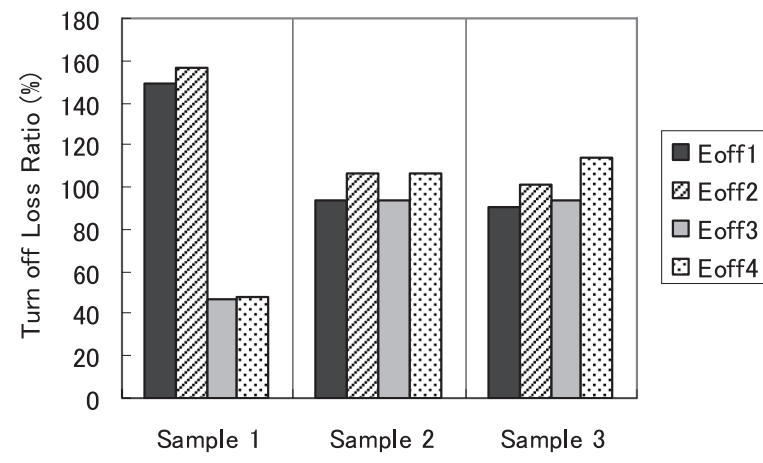

図 14 各解析サンプルのターンオフ損失比率

Fig. 14. Turn off loss ratio of analysis models.

まとめにし，ゲート配線は一方から上方に引き出している。 制御用ソース配線はゲート配線と同じサイドの一本のみに している。ゲート配線ループを yz平面ではなく, $\mathrm{xy}$ 平面で 構成することで, 過渡電流ばらつきを解析モデル 1 の FET1 と FET2 のばらつき程度に低減するためである。

図 13 に, 解析サンプル 3 の解析結果を示す。解析サン プル 1 で見られたような極端な電流ばらつきはなく, 過渡 電流ばらつきが抑制されている。このように，並列接続さ れた MOSFET 間のゲート配線ループを，磁束密度の低い 面上で構成し，ゲート配線ループと主回路配線間の磁気結 合を低減することで，スイッチング時の過渡電流ばらつき を抑制することができる。

〈4·3〉 ターンオフ損失比較 図 14 に, 各解析サンプ ルにおける MOSFET のターンオフ損失比率を示す。解析

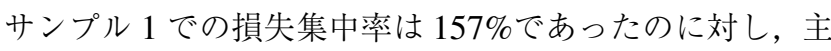
回路配線構造を最適化した解析サンプル 2 は $106 \%$, ゲー 卜配線構造を最適化した解析サンプル 3 は $114 \%$ に低減で きた。

\section{5. まとめ}

MOSFET を多並列接続したパワー半導体モジュールにお いて, 三次元電磁界解析と回路解析を用いて, 配線構造が スイッチング損失ばらつきに与える影響の定量的評価を行

い,以下の結論を得た。

・スイッチング時の急峻な電流変化によって発生する磁 束が，並列接続された MOSFET 間のゲート配線ルー プに鎖交することで，ゲート配線ループに誘導起電圧 が発生し，スイッチング損失ばらつきが発生する。

・ゲート配線ループに発生する誘導起電圧を低減するた めには, パワー半導体モジュール内の磁束密度分布を 把握し, 磁束密度の低い平面上でゲート配線ループを 構成する必要がある。

・MOSFET を多並列接続したパワー半導体モジュールで は，ゲート配線ループと外部接続端子の配列方向を垂 直にすることが，スイッチング損失ばらつき低減に有 効である。

(平成 20 年 3 月 21 日受付, 平成 21 年 1 月 7 日再受付)

\section{文献}

（1）大井健史：「パワーモジュールの分布定数抽出と動特性解析」, 三菱 電機技報, Vol.77, No.9 (2003-9)

(2) T. Okuda: "High-speed gate voltage control method equalizing loss of many parallel MOSFETs", 電学論 D, 124, No.10 (2004-10)

(3) 小谷和也·田多信光・本島研二:「パワーデバイス応用構造技術の検 討」, 電学研資, SPC-70, pp.73-76 (1998)

奥 田達 也（正員） 1973 年 6 月 7 日生。1998 年 3 月東京工

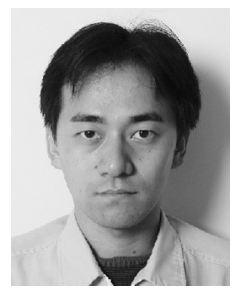
業大学大学院理工学研究科電気・電子工学専攻修 士課程修了。同年 4 月三菱電機 (株) 入社, 現在 に至る。主として, パワーエレクトロニクス装置 の研究・開発に従事。

浦 壁 隆 浩

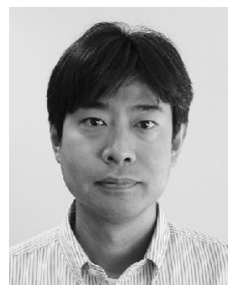

大 井 健 史

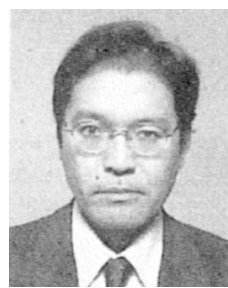

（正員） 1964 年 4 月 16 日生。 1988 年 3 月慶応 義塾大学計測工学科卒業。同年三菱電機 (株) 入 社。以来, 平面形蛍光ランプ, PDP, 低温 polySiTFT-LCD ドライバ, 配列形放電ディスプレイ, HID ランプ点灯装置の開発に従事。 